\title{
Non-Metastatic Extraskeletal Ewing
}

\section{Sarcoma}

National Cancer Institute

\section{Source}

National Cancer Institute. Non-Metastatic Extraskeletal Ewing Sarcoma. NCI Thesaurus.

Code C8802.

Ewing sarcoma that arises from the soft tissue and is confined to the site in which it initially manifested. 